\title{
Prognostic significance of cell cycle- associated proteins p16, pRB, cyclin D1 and p53 in resected oropharyngeal carcinoma
}

\author{
Michaela Plath ${ }^{1,2}$, Martina A. Broglie ${ }^{1,4}$, Diana Förbs ${ }^{3}$, Sandro J. Stoeckli ${ }^{1}$ and Wolfram Jochum ${ }^{3^{*}}$ (D)
}

\begin{abstract}
Background: Human papillomavirus (HPV)-related oropharyngeal squamous cell carcinoma (OPSCC) has an improved outcome and may allow for treatment de-escalation. High-risk HPV (HR-HPV) infection is associated with deregulated expression of the cell cycle-associated proteins p16 $6^{\mathrm{INK} 4}, \mathrm{pRB}, \mathrm{cyclin} \mathrm{D} 1$ and $\mathrm{p} 53$. The objective of this study was to assess cell cycle proteins as potential surrogate markers for HR-HPV DNA testing to identify OPSCC with favorable prognosis after resection.
\end{abstract}

Methods: Tissue microarray cores of 313 surgically treated OPSCC were stained for p16 $6^{\text {INK4a }}$, pRB, cyclin D1 and p53 using immunohistochemistry. Protein expression was scored as high or low based on the proportion of positive carcinoma cells. Tumor samples were analysed for HR-HPV DNA with polymerase chain reaction-based testing. Associations between cell cycle protein expression and HR-HPV DNA status were evaluated by calculating sensitivity, specificity, predictive values, and diagnostic odds ratios (DOR). Kaplan-Meier and Cox regression analysis were applied to evaluate associations between cell cycle protein expression and patient outcome.

Results: High expression of p16 ${ }^{\text {INK4a }}$, cyclin D1, pRB and p53 in tumor cells were observed in 51.8\%, 51.4\%, 41.9\% and 33.5\% of OPSCC, respectively. HR-HPV DNA positive were 158/313 (50.5\%) tumor samples (HPV16: 147, HPV18: 1, HPV33: 5, HPV35: 2, HPV56: 2, and HPV59: 1). P16 $6^{\text {INK4a }}$ showed a higher DOR to predict HR-HPV DNA positivity than pRB, cyclin D1 and p53. Both the p16 $6^{\mathrm{INK} 4 \mathrm{a}} / \mathrm{pRB}$ and the $\mathrm{p} 16^{\mathrm{INK} 4 \mathrm{a}} / \mathrm{pRB} / \mathrm{cyclin} \mathrm{D} 1 / \mathrm{p} 53$ signatures had lower DOR

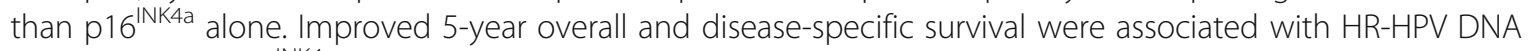
positivity, high p16 $6^{\text {INK4a }}$, low pRB, low cyclin D1, and low p53 expression. Associations with improved outcome were also observed for the marker combinations high $\mathrm{p} 16^{\text {INK4a }}$ /positive HR-HPV DNA, high $\mathrm{p} 16^{\text {INK4a }} /$ low pRB and high p16 INK4a/low pRB/low cyclin D1/low p53. In a multivariate analysis adjusted for age, smoking history, pT and pN category, high $16^{\mathrm{INK} 4 \mathrm{a}}$ expression showed the lowest hazard ratio for death.

Conclusions: High p16 ${ }^{\text {INK4a }}$ expression is a reliable marker for survival prognostication in surgically treated OPSCC patients. Protein signatures including the pRB, cyclin D1 and p53 proteins do not further increase the prognostic performance of p16 $6^{\text {INK4a }}$ as a single marker.

Keywords: Oropharyngeal squamous cell carcinoma, Human papillomavirus, p16, Retinoblastoma protein, Cyclin D1, p53, Prognosis

\footnotetext{
* Correspondence: wolfram.jochum@kssg.ch

${ }^{3}$ Institute of Pathology, Kantonsspital St. Gallen, Rorschacher Strasse 95, 9007

St. Gallen, Switzerland

Full list of author information is available at the end of the article
}

(c) The Author(s). 2018 Open Access This article is distributed under the terms of the Creative Commons Attribution 4.0 International License (http://creativecommons.org/licenses/by/4.0/), which permits unrestricted use, distribution, and reproduction in any medium, provided you give appropriate credit to the original author(s) and the source, provide a link to the Creative Commons license, and indicate if changes were made. The Creative Commons Public Domain Dedication waiver (http://creativecommons.org/publicdomain/zero/1.0/) applies to the data made available in this article, unless otherwise stated. 


\section{Background}

High-risk human papillomavirus (HR-HPV) infection is a major cause of oropharyngeal squamous cell carcinoma (OPSCC) [1]. HPV-related OPSCC has better prognosis, irrespective of disease stage [2-4]. Treatment options for patients with early OPSCC include surgical resection with or without adjuvant radio (chemo)therapy or primary radio(chemo)therapy. Identification of the prognostic impact of HPV has lead to the development of risk-adapted staging systems for HPV-related OPSCC, and to the adaptation of the current American Joint Committee on Cancer (AJCC)/Union for International Cancer Control (UICC) TNM staging classification [2-5]. These developments underscore the increasing clinical significance of HPV status in OPSCC und the need for establishing the HPV status of OPSCC prior to treatment initiation.

HR-HPV infection of tumor cells is associated with the expression of the viral E6 and E7 oncoproteins [6]. Both proteins are essential to induce and maintain cellular transformation, due to their interference with cell cycle control, apoptosis, and genomic stability. In addition to other target proteins, E6 promotes the degradation of the p53 protein, which regulates growth arrest and apoptosis after DNA damage. E7 increases degradation of the cellular retinoblastoma protein ( $\mathrm{pRB}$ ), which leads to up-regulation of p16 ${ }^{\text {INK4a }}$ and down-regulation of cyclin D1. Disruption of both the p53 and pRB pathways promotes S-phase entry. The tumor cell signature of high $\mathrm{p} 16^{\mathrm{INK} 4 \mathrm{a}}$ expression and low/absent expression of cyclin D1, pRB and p53 correlates with HR-HPV infection [7]. Furthermore, deregulated expression of these cell cycle regulators has been linked to outcome prediction in OPSCC. High $\mathrm{p} 16^{\mathrm{INK} 4 \mathrm{a}}$ expression of tumor cells was associated with favorable prognosis and high cyclin D1 and p53 expression of tumor cells was linked to poor outcome [8-19]. However, evaluation of the prognostic significance of deregulated cell cycle regulator expression in OPSCC has been restricted by usage of different immunohistochemical staining methods, scoring systems, and thresholds, and most importantly heterogeneity of patient cohorts with respect to disease stage and treatment modalities.

The objectives of our study were to validate $\mathrm{p} 16^{\mathrm{INK} 4 \mathrm{a}}$ as a prognostic marker in a large cohort of surgically treated OPSCC, and to directly compare the performance of p16 ${ }^{\mathrm{INK} 4 \mathrm{a}}$ with $\mathrm{pRB}$, cyclin D1 and p53 to predict patient outcome. The second objective was to evaluate the cell cycle proteins p16 ${ }^{\mathrm{INK} 4 \mathrm{a}}$, pRB, cyclin D1 and p53 as surrogate markers for HR-HPV DNA positivity.

\section{Methods}

\section{Patient population}

The cohort of this study represents a subgroup of a previous reported cohort [20]. Demographic and clinical data were collected by chart review. The patients were categorized into two groups based on treatment: Group 1 was treated with resection alone $(n=104 ; 33.2 \%)$, group 2 with resection and adjuvant radio(chemo)therapy ( $n=209$; $66.8 \%$ ). Pathological staging was performed using the 7th edition of the AJCC/UICC TNM classification system (2010).

\section{Histological analysis}

One representative formalin-fixed paraffin-embedded tissue block of each OPSCC resection specimen was retrieved. Hematoxylin and eosin (H\&E) staining of sections was performed using standard techniques. Stained sections underwent histological review to confirm the presence of carcinoma.

\section{Tissue microarray}

Formalin-fixed paraffin-embedded OPSCC tissue samples were used to construct tissue microarrays (TMA). Three cores (diameter $2 \mathrm{~mm}$ ) with tumor tissue were punched out of each donor block and transferred to the recipient block. Tissue cores from tonsils of non-tumor patients were included as controls. H\&E stained TMA sections were microscopically evaluated for the presence of tumor cells.

\section{Immunohistochemistry}

Three- $\mu \mathrm{m}$ thick tissue microarray sections were deparaffinized followed by antigen retrieval (EDTA pH 9.0, $95^{\circ} \mathrm{C}$, 30 min). Stainings were performed on a Leica BOND MAX instrument (Leica) using the Bond Polymer Refine detection kit (Leica) and the following primary antibodies: $116^{\text {INK4a }}$ (clone E6H4, dilution 1:10, 30 min; MTM Laboratories, Heidelberg, Germany), pRB (clone 13A10, dilution 1:100, 15 min; Novocastra), cyclin D1 (clone SP4, dilution 1:50, $30 \mathrm{~min}$; ThermoScientific), and p53 (clone DO-7, dilution 1:150, 30 min; Dako). Marker expression was scored as high or low based on the proportion of positive carcinoma cells (high $\mathrm{p} 16^{\mathrm{INKa}}$ : more than $70 \%$ of tumor cells; high pRB, cyclin D1, or p53: more than $25 \%$ of tumor cell nuclei) $[19,21]$.

\section{HPV DNA analysis}

Tumor cells were located and marked on H\&E stained tissue sections obtained from paraffin blocks of primary OPSCC. Selective dissection of tumor cells was performed from three to five $4 \mu \mathrm{m}$ thick serial tissue sections of the same paraffin block and genomic DNA was prepared. HPV DNA was detected by polymerase chain reaction (PCR)-based amplification using the L1C1/L1C2 consensus primer set as previously described [22]. PCR products were purified using the QIAGEN PCR purification Kit (QIAGEN) and underwent direct sequencing for HPV typing. Negative and positive controls were included in each HPV PCR run. Beta-globin PCR was performed for samples with negative HPV PCR to test for effective DNA extraction and 
DNA integrity. Only samples with amplifiable DNA were scored as negative for HPV.

\section{Statistical analysis}

All analyses were performed with the SPSS Statistics 22 software (IBM Corporation, Armonk NY). Demographic and clinicopathological patient characteristics were investigated with descriptive statistics. Associations between cell cycle protein expression and HR-HPV DNA status were analyzed using the chi-square test. Specificity, sensitivity, positive predictive values (PPV), negative predictive values (NPV), and diagnostic odds ratios (DOR) were calculated to evaluate cell cycle proteins and expression signatures as potential surrogate markers for HR-HPV DNA positivity. Overall survival (OS) was defined as time from the date of cancer diagnosis to the date of death, disease-specific survival (DSS) as the time from the date of cancer diagnosis to the date of death from OPSCC. Five-year OS and DSS rates were calculated using the Kaplan-Meier method. Univariate
Cox proportional hazard models were used to explore associations between patient characteristics, biomarker results, OS and DSS. Hazard ratios (HR) with 95\% confidence intervals were calculated. The Cox proportional hazard model was used for multivariate analysis. $P$ values of $<0.05$ were considered statistically significant.

\section{Results}

\section{Patient cohort}

Three hundred thirteen patients with surgically treated and histologically confirmed OPSCC were included in the analysis. The clinicopathological characteristics of the patient cohort are shown in Table 1.

\section{Cell cycle protein expression}

In non-neoplastic tonsils, scattered epithelial cells showed weak to moderate $\mathrm{p} 16^{\mathrm{INK} 4 \mathrm{a}}$ reactivity. $\mathrm{pRB}$ was strongly expressed in the nuclei of basal and parabasal epithelial

Table 1 Clinicopathological characteristics of the study population

\begin{tabular}{|c|c|c|c|}
\hline Characteristic & $\begin{array}{l}\text { Entire cohort } \\
(n=313)\end{array}$ & $\begin{array}{l}\text { Resection only group } \\
(n=104)\end{array}$ & $\begin{array}{l}\text { Resection with adjuvant therapy group } \\
(n=209)\end{array}$ \\
\hline Mean age (range) & $68(35-101)$ & $68(47-101)$ & $68(35-100)$ \\
\hline \multicolumn{4}{|l|}{ Gender } \\
\hline Male & $230(73.5 \%)$ & $71(68.3 \%)$ & $159(76.1 \%)$ \\
\hline Female & $83(26.5 \%)$ & $33(31.7 \%)$ & $50(23.9 \%)$ \\
\hline \multicolumn{4}{|l|}{ Smoking history } \\
\hline$>10$ pack-years & $221(70.6 \%)$ & $78(75.0 \%)$ & $143(68.4 \%)$ \\
\hline$<10$ pack-years & 92 (29.4\%) & $26(25.0 \%)$ & $66(31.6 \%)$ \\
\hline \multicolumn{4}{|l|}{ Alcohol intake } \\
\hline$<3 \mathrm{U} / \mathrm{d}$ & $164(52.4 \%)$ & $52(50.0 \%)$ & $112(53.6 \%)$ \\
\hline$>3 \mathrm{U} / \mathrm{d}$ & $113(36.1 \%)$ & $40(38.5 \%)$ & 73 (34.9\%) \\
\hline Missing data & $36(11.5 \%)$ & $12(11.5 \%)$ & $24(11.5 \%)$ \\
\hline \multicolumn{4}{|l|}{ Primary site } \\
\hline Tonsil & $217(69.3 \%)$ & 68 (65.4\%) & $149(71.3 \%)$ \\
\hline Base of tongue & $58(18.5 \%)$ & $16(15.4 \%)$ & $42(20.1 \%)$ \\
\hline Posterior wall / soft palate & $38(12.2 \%)$ & 20 (19.2\%) & $18(8.6 \%)$ \\
\hline \multicolumn{4}{|l|}{ Tumor stage } \\
\hline $\mathrm{T} 1 / \mathrm{T} 2$ & $263(84.0 \%)$ & 96 (92.3\%) & 167 (79.9\%) \\
\hline $\mathrm{T} 3 / \mathrm{T} 4$ & $50(16.0 \%)$ & $8(7.7 \%)$ & $42(20.1 \%)$ \\
\hline \multicolumn{4}{|l|}{ Nodal stage } \\
\hline NO & 92 (29.4\%) & $58(55.8 \%)$ & 34 (16.3\%) \\
\hline $\mathrm{N}+$ & $221(70.6 \%)$ & $46(44.2 \%)$ & $175(83.7 \%)$ \\
\hline \multicolumn{4}{|l|}{ HR-HPV DNA } \\
\hline Positive & $158(50.5 \%)$ & 42 (40.4\%) & $116(55.5 \%)$ \\
\hline Negative & $155(49.5 \%)$ & $62(59.6 \%)$ & 93 (44.5\%) \\
\hline 5-year overall survival rate & $76.1 \%$ & $69.8 \%$ & $79.1 \%$ \\
\hline 5-year disease-specific survival rate & $85.2 \%$ & $83.1 \%$ & $86.2 \%$ \\
\hline
\end{tabular}


cells, which also showed weak to moderate nuclear cyclin D1 and p53 staining (data not shown).

We next evaluated cell cycle protein expression in tissue cores of 313 OPSCC (Fig. 1, Table 2). Strong p16 $6^{\mathrm{INK} 4 \mathrm{a}}$ staining in more than $70 \%$ of carcinoma cells was observed in $52.1 \%$ of OPSCC. pRB and cyclin D1 reactivity was low (< $25 \%$ of tumor cells) or absent in $48.6 \%$ and $57.8 \%$ of OPSCC, respectively. Nuclear p53 positivity stronger than in tonsillar epithelial cells was observed in $33.5 \%$ of tumors. A high $\mathrm{p} 16^{\mathrm{INK} 4 \mathrm{a}} /$ low $\mathrm{pRB}$ signature of tumor cells was present in $45.4 \%$ of OPSCC. Thirty-eight percent of the OPSCC displayed a high $16^{\mathrm{INK} 4 \mathrm{a}} /$ low $\mathrm{pRB} /$ low cyclin D1/ low p53 signature.

\section{Association of cell cycle protein expression with HR-HPV DNA}

HPV DNA testing was conclusive in all 313 OPSCC. 158 (50.5\%) tumors were HR-HPV DNA positive (HPV16: 147, HPV18: 1, HPV33: 5, HPV35: 2, HPV56: 2, and HPV59: 1). HR-HPV DNA positive OPSCC were positive for $\mathrm{p} 16^{\mathrm{INK} 4 \mathrm{a}}, \mathrm{pRB}$, cyclin D1and $\mathrm{p} 53$ in $91.8 \%, 17.1 \%$, $15.8 \%$, and $14.6 \%$, respectively (Table 2 ). There was a strong association between HR-HPV DNA positivity and high $\mathrm{p} 16^{\mathrm{INK} 4 \mathrm{a}}$ expression. In addition, HR-HPV DNA positivity was also correlated with low pRB, low cyclin D1 and low p53 expression. There was also a strong association between HR-HPV DNA positivity and both the 2-marker signature high $\mathrm{p} 16^{\mathrm{INK} 4 \mathrm{a}} / \mathrm{low} \mathrm{pRB}$ and the 4-marker signature high $\mathrm{p} 16^{\mathrm{INK} 4 \mathrm{a}} /$ low $\mathrm{pRB} /$ low cyclin D1/ low p53. High $\mathrm{p} 16^{\mathrm{INK} 4 \mathrm{a}}$ expression alone displayed the highest sensitivity value for HR-HPV DNA positivity. In contrast, the 4-marker signature showed the highest specificity value. To directly compare the performance of individual cell cycle proteins and the two marker signatures to detect HR-HPV DNA positive OPSCC, diagnostic odds ratios (DOR) were calculated. The value of a DOR ranges from 0 to infinity, with higher values indicating better discriminatory test performance. The largest DOR value was observed for high p16 ${ }^{\mathrm{INK} 4 \mathrm{a}}$ expression alone (Table 2).

\section{Association of cell cycle protein expression with survival after resection}

The mean follow-up period of the cohort was 119 months (range 6-172 months). The 5-year OS and DSS rates were $76.1 \%$ and $85.2 \%$, respectively. Kaplan-Meier analysis demonstrated that both improved OS and DSS were associated with HR-HPV DNA positivity, and high $\mathrm{p} 16^{\mathrm{INK} 4 \mathrm{a}}$, low pRB, low cyclin D1 and low p53 expression of tumor cells (Fig. 2, Table 3).

Univariate Cox regression analysis revealed reduced overall risks of death for OPSCC with HR-HPV DNA positivity and high $\mathrm{p} 16^{\mathrm{INK} 4 \mathrm{a}}$ expression (Table 3). In contrast, hazard ratios (HR) were increased for OPSCC with high pRB, high cyclin D1, or high p53 expression. The combined parameters high $\mathrm{p} 16^{\mathrm{INK4a}} /$ positive HR-HPV DNA, high $\mathrm{p} 16^{\text {INK4a }} /$ low pRB, and high $16^{\text {INK4a }} /$ low pRB/low cyclin D1/low p53 were also associated with reduced overall risks of death. Comparable results were obtained for the risk of disease-specific death, which was evaluated as an additional outcome parameter (Table 3). We also used Cox proportional hazard models adjusted for age, smoking history, $\mathrm{pT}$ stage and $\mathrm{pN}$ stage to evaluate and compare the prognostic impact of the various parameters. Parameters retained prognostic significance in multivariate analyses except high cyclin D1 and p53 expression (Table 4).

We also performed subgroup analyses for OPSCC patients with or without adjuvant treatment after resection. For both subgroups, similar associations between the various parameters and patient outcome were observed as for the entire cohort (data not shown).

\section{Discussion}

Among patients with OPSCC, HR-HPV infection of tumor cells is associated with favorable prognosis, and therefore may identify patients who benefit from treatment de-escalation. Various methods are available for HR-HPV testing. HR-HPV E6/E7 messenger RNA (mRNA) expression demonstrated by reverse transcriptase-PCR or RNA in situ hybridization (ISH) is considered the most specific marker for biologically relevant HPV infection because it identifies transcriptionally active HPV infection and indicates the translation of the viral E6 and E7 oncoproteins [23]. In addition, HR-HPV DNA can be detected by polymerase chain reaction (PCR)-based assays or ISH techniques with HPV type-specific probes [24]. HPV E6 and E7 oncoproteins induce $\mathrm{p} 16^{\mathrm{INK} 4 \mathrm{a}}$ protein overexpression and suppress the expression of the cell cycle proteins pRB, cyclin D1 and p53 in infected cells [6]. Recent studies have shown that the combined detection of HR-HPV DNA (by PCR or ISH) and $\mathrm{p} 16^{\mathrm{INK4a}}$ protein overexpression identifies transcriptionally active HR-HPV infection with specificity and sensitivity comparable to those of E6/E7 mRNA expression $[14,23,25]$. However, the availability of molecular detection methods for HR-HPV DNA or HR-HPV E6/E7 mRNA is limited. In contrast, immunohistochemistry for protein expression analysis is broadly available and therefore may be used as a fast and inexpensive methodology to assess tumor cells for HR-HPV-related protein deregulation in the clinical setting. The 8th edition TNM classification for head and neck cancer distinguishes between OPSCC with and without HPV association, and recommends p $16^{\mathrm{INK} 4 \mathrm{a}}$ immunostaining for the identification of tumors with positive HPV status, based on the conclusion that $\mathrm{p} 16^{\mathrm{INK} 4 \mathrm{a}}$ is a reliable surrogate marker for oncologically relevant HPV infection [26]. In HR-HPV infected tumor cells, increased $\mathrm{p} 16^{\mathrm{INK} 4 \mathrm{a}}$ expression is a direct consequence of pRB inactivation by the HPV oncoprotein E7, which 


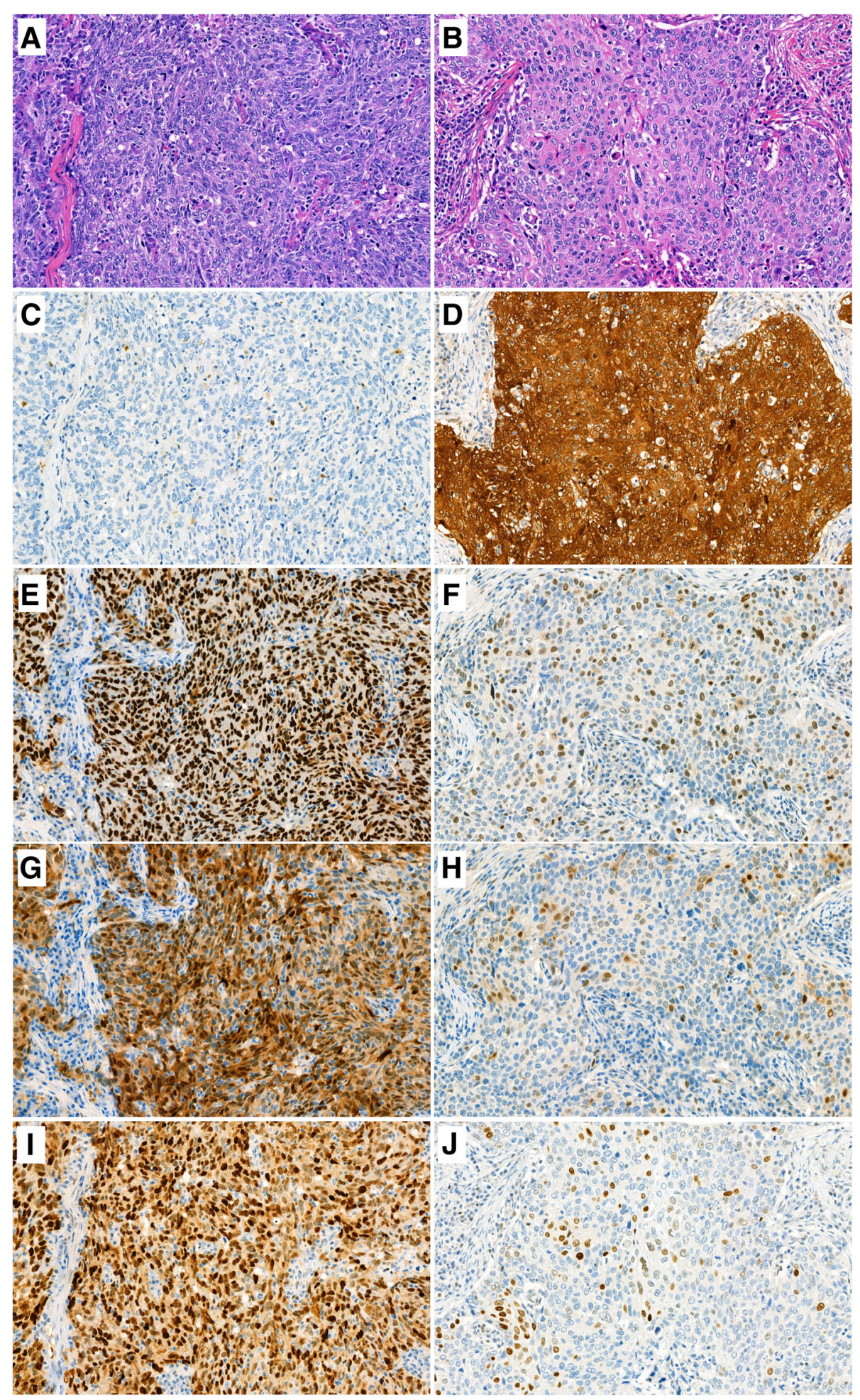

Fig. 1 Expression of cell cycle-associated proteins in oropharyngeal squamous cell carcinoma. Histological findings $(\mathbf{a}, \mathbf{b})$ and expression of the p16 ${ }^{\text {INK4a }}(\mathbf{c}, \mathbf{d})$, pRB $(\mathbf{e}, \mathbf{f})$, cyclin D1 $(\mathbf{g}, \mathbf{h})$ and p53 $(\mathbf{i}, \mathbf{j})$ proteins in representative HR-HPV positive $(\mathbf{b}, \mathbf{d}, \mathbf{f}, \mathbf{h}, \mathbf{j})$ and HR-HPV negative OPSCC $(\mathbf{a}, \mathbf{c}$, e, $\mathbf{g}$, i). Original magnification, $400 x$ 
Table 2 Association between cell cycle protein expression and HR-HPV DNA status

\begin{tabular}{|c|c|c|c|c|c|c|c|c|c|c|c|}
\hline \multirow{2}{*}{$\begin{array}{l}\text { Cell cycle } \\
\text { protein }\end{array}$} & \multirow{2}{*}{$\begin{array}{l}\text { Entire } \\
\text { cohort } \\
(n=313)\end{array}$} & \multirow{2}{*}{$\begin{array}{l}\text { HR-HPV DNA } \\
\text { negative } \\
(n=155)\end{array}$} & \multicolumn{3}{|c|}{ HR-HPV DNA positive } & \multirow{2}{*}{$\begin{array}{l}\text { Pearson Chi- } \\
\text { square } \\
p \text { value }\end{array}$} & \multirow{2}{*}{$\begin{array}{l}\text { Sensitivity } \\
(\%)\end{array}$} & \multirow{2}{*}{$\begin{array}{l}\text { Specificity } \\
(\%)\end{array}$} & \multirow{2}{*}{$\begin{array}{l}\text { PPV } \\
(\%)\end{array}$} & \multirow{2}{*}{$\begin{array}{l}\text { NPV } \\
(\%)\end{array}$} & \multirow[t]{2}{*}{ DOR } \\
\hline & & & $\begin{array}{l}\text { All } \\
(n=158)\end{array}$ & $\begin{array}{l}\text { HPV16 } \\
(n=147)\end{array}$ & $\begin{array}{l}\text { Non-HPV16 } \\
(n=11)\end{array}$ & & & & & & \\
\hline \multicolumn{6}{|l|}{ p16 INK4a } & $<0.001$ & 91.8 & 89.0 & 89.5 & 91.4 & 90.3 \\
\hline Low & $\begin{array}{l}151 \\
(48.2 \%)\end{array}$ & $138(89.0 \%)$ & $13(8.2 \%)$ & $13(8.8 \%)$ & $0(0 \%)$ & & & & & & \\
\hline High & $\begin{array}{l}162 \\
(51.8 \%)\end{array}$ & $17(11.0 \%)$ & $\begin{array}{l}145 \\
(91.8 \%)\end{array}$ & $\begin{array}{l}134 \\
(91.2 \%)\end{array}$ & $\begin{array}{l}11 \\
(100.0 \%)\end{array}$ & & & & & & \\
\hline \multicolumn{6}{|l|}{ pRB } & $<0.001$ & 82.9 & 86.5 & 86.2 & 83.2 & 31.1 \\
\hline Low & $\begin{array}{l}152 \\
(48.6 \%)\end{array}$ & $21(13.5 \%)$ & $\begin{array}{l}131 \\
(82.9 \%)\end{array}$ & $\begin{array}{l}121 \\
(82.3 \%)\end{array}$ & $10(91.0 \%)$ & & & & & & \\
\hline High & $\begin{array}{l}161 \\
(51.4 \%)\end{array}$ & $134(86.5 \%)$ & $\begin{array}{l}27 \\
(17.1 \%)\end{array}$ & $\begin{array}{l}26 \\
(17.7 \%)\end{array}$ & $1(9.0 \%)$ & & & & & & \\
\hline \multicolumn{6}{|l|}{ Cyclin D1 } & $<0.001$ & 84.2 & 68.4 & 73.1 & 80.9 & 11.5 \\
\hline Low & $\begin{array}{l}181 \\
(57.8 \%)\end{array}$ & $48(31 \%)$ & $\begin{array}{l}133 \\
(84.2 \%)\end{array}$ & $\begin{array}{l}124 \\
(84.3 \%)\end{array}$ & $9(81.8 \%)$ & & & & & & \\
\hline High & $\begin{array}{l}132 \\
(42.2 \%)\end{array}$ & 107 (69\%) & $\begin{array}{l}25 \\
(15.8 \%)\end{array}$ & $\begin{array}{l}23 \\
(15.7 \%)\end{array}$ & $2(18.2 \%)$ & & & & & & \\
\hline \multicolumn{6}{|l|}{ p53 } & $<0.001$ & 85.4 & 53.9 & 64.9 & 78.1 & 6.8 \\
\hline Low & $\begin{array}{l}208 \\
(66.5 \%)\end{array}$ & $73(47.1 \%)$ & $\begin{array}{l}135 \\
(85.4 \%)\end{array}$ & $\begin{array}{l}127 \\
(86.4 \%)\end{array}$ & $8(72.7 \%)$ & & & & & & \\
\hline High & $\begin{array}{l}105 \\
(33.5 \%)\end{array}$ & $82(52.9 \%)$ & $\begin{array}{l}23 \\
(14.6 \%)\end{array}$ & $\begin{array}{l}20 \\
(13.6 \%)\end{array}$ & $3(27.3 \%)$ & & & & & & \\
\hline \multicolumn{6}{|l|}{$\mathrm{p} 16^{\mathrm{INK} 4 \mathrm{a} / \mathrm{pRB}}$} & $<0.001$ & 82.9 & 92.9 & 92.3 & 84.2 & 63.8 \\
\hline High/low & $\begin{array}{l}142 \\
(45.4 \%)\end{array}$ & $11(7.1 \%)$ & $\begin{array}{l}131 \\
(82.9 \%)\end{array}$ & $\begin{array}{l}121 \\
(82.3 \%)\end{array}$ & $10(90.9 \%)$ & & & & & & \\
\hline Other & $\begin{array}{l}171 \\
(54.6 \%)\end{array}$ & $144(92.9 \%)$ & $\begin{array}{l}27 \\
(17.1 \%)\end{array}$ & $\begin{array}{l}26 \\
(17.7 \%)\end{array}$ & $1(9.1 \%)$ & & & & & & \\
\hline \multicolumn{6}{|c|}{ p16 ${ }^{\text {INK4a/pRB/ cyclin D1/p53 }}$} & $<0.001$ & 68.4 & 93.5 & 91.5 & 74.4 & 30.9 \\
\hline $\begin{array}{l}\text { High/low/ } \\
\text { low/low }\end{array}$ & $\begin{array}{l}118 \\
(37.7 \%)\end{array}$ & $10(6.5 \%)$ & $\begin{array}{l}108 \\
(68.4 \%)\end{array}$ & $\begin{array}{l}102 \\
(69.4 \%)\end{array}$ & $6(54.6 \%)$ & & & & & & \\
\hline Other & $\begin{array}{l}195 \\
(62.3 \%)\end{array}$ & 145 (93.5\%) & $\begin{array}{l}50 \\
(31.6 \%)\end{array}$ & $\begin{array}{l}45 \\
(30.6 \%)\end{array}$ & $5(45.4 \%)$ & & & & & & \\
\hline
\end{tabular}

PPV positive predictive value, NPV negative predictive value (\%); and DOR diagnostic odds ratio. Non-HPV16 group included tumors positive for HPV18, HPV33, HPV35, HPV56, or HPV59

induces degradation through the ubiquitin-proteasome pathway [27]. However, using $\mathrm{p} 16^{\mathrm{INK} 4 \mathrm{a}}$ expression alone as a biomarker for positive HR-HPV status may have limitations due to HR-HPV-independent mechanisms of up-regulation.

In our study, we aimed to evaluate pRB, cyclin D1 and p53 as alternative marker for HR-HPV DNA positivity, and to address the question whether protein signatures including pRB, cyclin D1 and p53 may increase the diagnostic performance of $\mathrm{p} 16^{\mathrm{INK} 4 \mathrm{a}}$ alone. In accordance with other studies, we observed that HPV-associated OPSCC are characterized by strong $\mathrm{p} 16^{\mathrm{INK} 4 \mathrm{a}}$ expression and low or absent expression of pRB, cyclin D1, und p53 [7, 18, 19]. Among the four cell cycle-associated proteins, high $\mathrm{p} 16^{\mathrm{INK} 4 \mathrm{a}}$ staining showed the strongest association with HR-HPV DNA positivity when evaluated as a single marker (sensitivity $92 \%$, specificity 88\%). The associations between low/ absent expression of pRB, cyclin D1, or p53 alone and HR-HPV DNA positivity were significantly lower. In comparison to high $\mathrm{p} 16^{\mathrm{INK} 4 \mathrm{a}}$ expression alone, we observed higher specificity values for the 2-marker signature high $\mathrm{p} 16^{\text {INK4a }} /$ low $\mathrm{pRB}$ and the 4-marker signature $\mathrm{p} 16^{\mathrm{INK} 4 \mathrm{a}} /$ $\mathrm{pRB} /$ cyclin D1/p53, but reduced sensitivity values. Using the diagnostic odds ratio as a performance parameter, high p16 ${ }^{\text {INK4a }}$ expression alone was the best immunohistochemical marker for HR-HPV DNA positivity. Our findings confirm $\mathrm{p} 16^{\mathrm{INK} 4 \mathrm{a}}$ as a reliable surrogate marker for HR-HPV infection in OPSCC. They also indicate that signatures including the $\mathrm{pRB}$, cyclin $\mathrm{D} 1$ and $\mathrm{p} 53$ proteins do not significantly increase the diagnostic performance of p $16^{\text {INK4a }}$ as a single marker.

Treatment options for patients with early OPSCC include surgical resection with or without adjuvant radio(chemo)therapy, or primary radio(chemo)therapy. In addition to its 

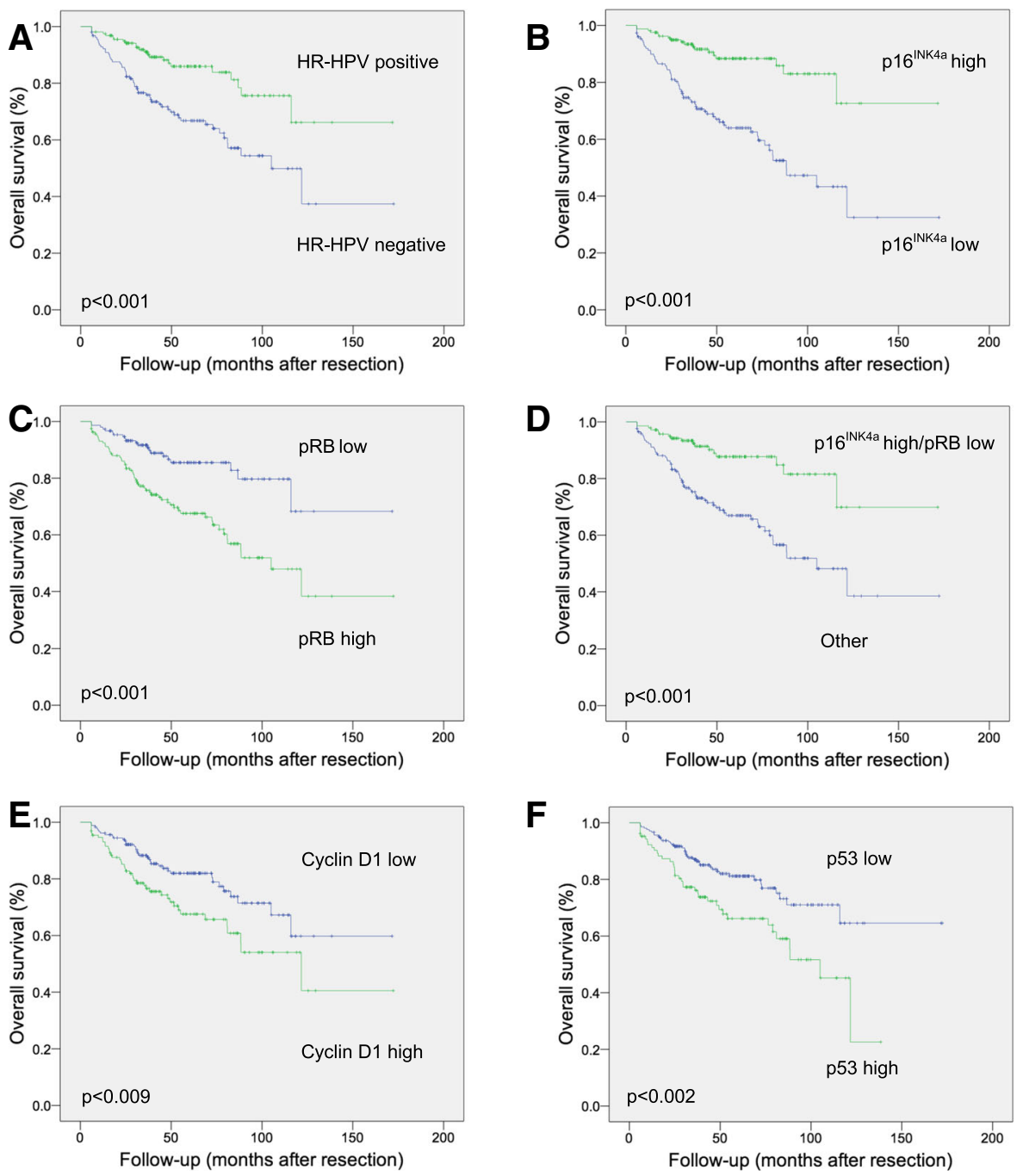

Fig. 2 Overall survival after resection in patients with oropharyngeal squamous cell carcinoma. Kaplan-Meier analyses revealed associations between

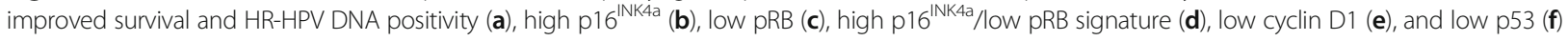

role in tumorigenesis, HR-HPV infection identifies OPSCC patients with improved survival who may benefit from treatment de-escalation [10, 20, 28]. Previous studies have shown that HR-HPV DNA detection alone, the combined detection of HR-HPV DNA and $16^{\text {INK4a }}$ protein, $16^{\mathrm{INK4a-}}$ protein expression alone, or HR-HPV E6/E7mRNA expression identify OPSCC patients with favorable prognosis [9-12, 14, 15]. Furthermore, poor prognosis has been linked to high cyclin D1 and p53 expression of tumor cells $[8,13,16-18]$. In the majority of theses studies, association analysis of the various markers with survival was confounded by treatment heterogeneity of cohorts and/or limited patient numbers. Only few previous studies have investigated cohorts of surgically treated OPSCC [18, 29-31]. In the current study, we analyzed the prognostic significance of cell cycle protein expression in a large cohort of surgically treated OPSCC patients from the same geographic region [20]. Univariate analysis revealed that improved outcome after resection (both 5-year OS and DSS) were associated with high $\mathrm{p} 16^{\mathrm{INK} 4 \mathrm{a}}$, low pRB, low cyclin D1, and low p53 expression. Furthermore, HR-HPV DNA positivity and the combined parameters high $\mathrm{p} 16^{\mathrm{INK4a}} /$ positive HR-HPV DNA, high $16^{\mathrm{INK} 4 \mathrm{a}} /$ low pRB, and high $16^{\mathrm{INK} 4 \mathrm{a}} /$ low pRB/low cyclin D1/low p53 were also associated with reduced risks of death. Parameters retained prognostic significance in multivariate analyses except high cyclin D1 and p53 expression. Our results confirm the findings of previous studies and validate them specifically for surgically treated OPSCC patients $[8-19,23]$. They indicate that high $\mathrm{p} 16^{\mathrm{INK} 4 \mathrm{a}}$ expression provides comparable prognostic information as HR-HPV DNA positivity in surgically treated OPSCC 
Table 3 Univariate analysis of overall and disease-specific survival for patients with OPSCC patients treated with resection

\begin{tabular}{|c|c|c|c|c|c|c|c|c|}
\hline \multirow{2}{*}{$\begin{array}{l}N=313 \\
\text { Parameter }\end{array}$} & \multicolumn{4}{|c|}{ 5-year overall survival } & \multicolumn{4}{|c|}{ 5-year disease-specific survival } \\
\hline & $\%$ & $P$ value & $\mathrm{HR}(95 \% \mathrm{Cl})$ & $P$ value & $\%$ & $P$ value & $\mathrm{HR}(95 \% \mathrm{Cl})$ & $P$ value \\
\hline Age $(>65$ y vs. $<65$ y) & $75.6 / 77.1$ & 0.83 & $1.05(0.66-1.68)$ & 0.83 & $85.3 / 84.9$ & 0.88 & $1.05(0.56-1.99)$ & 0.88 \\
\hline Smoking history (> 10 py vs. $<10$ py) & $70.9 / 88.5$ & 0.002 & $2.53(1.37-4.69)$ & 0.003 & $80.8 / 95.8$ & 0.003 & $4.19(1.49-11.77)$ & 0.006 \\
\hline Tumor stage (T3/T4 vs. T1/T2) & $64.7 / 78.5$ & 0.15 & $1.48(0.87-2.55)$ & 0.15 & $74.6 / 87.4$ & 0.023 & $2.15(1.09-4.21)$ & 0.03 \\
\hline Nodal stage (N+ vs. N0) & $73.5 / 82.0$ & 0.31 & $1.3(0.78-2.16)$ & 0.31 & $83.2 / 90.2$ & 0.14 & $1.77(0.82-3.84)$ & 0.15 \\
\hline HR-HPV DNA (Positive vs. negative) & $85.9 / 66.8$ & $<0.001$ & $0.39(0.24-0.64)$ & $<0.001$ & $91.6 / 78.9$ & $<0.001$ & $0.30(0.15-0.62)$ & 0.001 \\
\hline p16 INK4a (High vs. low) & $89.6 / 64.5$ & $<0.001$ & $0.29(0.15-0.44)$ & $<0.001$ & $93.2 / 80.9$ & $<0.001$ & $0.21(0.1-0.46)$ & $<0.001$ \\
\hline pRB (High vs. low) & $67.6 / 85.5$ & $<0.001$ & $2.68(1.63-4.43)$ & $<0.001$ & $78.8 / 92.2$ & $<0.001$ & $3.56(1.70-7.47)$ & 0.001 \\
\hline Cyclin D1 (High vs. low) & $67.6 / 82.0$ & 0.009 & $1,79(1.15-2.80)$ & 0.01 & $81.9 / 87.7$ & 0.068 & $1.76(0.95-3.25)$ & 0.07 \\
\hline p53 (High vs. low) & $66.2 / 81.2$ & 0.002 & $1.99(1.27-3.10)$ & 0.002 & $79.1 / 88.2$ & 0.053 & $1.82(0.98-3.36)$ & 0.06 \\
\hline High p16 $6^{\text {INK4a } / H R-H P V ~ D N A ~ p o s i t i v e ~ v s . ~ o t h e r s ~}$ & $85.9 / 66.8$ & $<0.001$ & $0.39(0.24-0.64)$ & $<0.001$ & $91.6 / 78.9$ & $<0.001$ & $0.30(0.15-0.62)$ & 0.001 \\
\hline High p16 $6^{\text {INK4a }} /$ low pRB vs. others & $87.7 / 67.0$ & $<0.001$ & $0.32(0.18-0.54)$ & $<0.001$ & 93.2/78.7 & $<0.001$ & $0.23(0.10-0.52)$ & $<0.001$ \\
\hline High p16 $16^{\text {NK4a }} /$ low pRB/low cyclin D1/low p53 vs. others & $88.3 / 69.9$ & $<0.001$ & $0.33(0.18-0.59)$ & $<0.001$ & $94.1 / 80.0$ & $<0.001$ & $0.21(0.08-0.55)$ & 0.001 \\
\hline
\end{tabular}

Abbreviations: $H R$ hazard ratio for death, $\mathrm{Cl}$ confidence interval; $p y$ pack-year. Log-rank test. $p<0.05$ was considered statistically significant

patients and may therefore serve as a reliable surrogate marker for improved prognosis, if HR-HPV DNA testing is not available.

Limitations of our study include that cell cycle protein expression analyses were performed on TMA cores that may not be representative of the whole tumor. However, various studies have shown excellent concordance between TMA spots and whole tissue sections in immunohistochemical analyses of multiple tumor types. Furthermore, each tumor was represented by three tissue cores in our study to increase concordance. Two individuals blinded for HR-HPV DNA results and clinical outcome information scored all immunohistochemical stainings. However, digital image analysis may have increased standardization of scoring. We used HR-HPV DNA positivity as the gold standard to evaluate cell cycle proteins as potential surrogate markers for HR-HPV infection. However, HR-HPV E6/E7 mRNA detection is considered the best marker for biologically relevant HR-HPV infection. Further studies are necessary to directly compare the performance of $\mathrm{p} 16^{\mathrm{INK} 4 \mathrm{a}}$ expression and HR-HPV E6/E7 mRNA detection in surgically treated OPSCC.

\section{Conclusion}

In conclusion, our results show that immunohistochemical demonstration of high $\mathrm{p} 16^{\mathrm{INK} 4 \mathrm{a}}$ expression in tumor cells is a reliable tool for survival prognostication in surgically treated OPSCC patients. Protein signatures including the pRB, cyclin D1 and p53 proteins do not further increase the prognostic and diagnostic performance of $\mathrm{p} 16^{\mathrm{INK} 4 \mathrm{a}}$ as a single marker. Therefore, $\mathrm{p} 16^{\mathrm{INK} 4 \mathrm{a}}$ may be used to select OPSCC patients with improved prognosis for treatment de-escalation, especially in the absence of HR-HPV DNA and HR-HPV E6/E7 mRNA testing.

Table 4 Multivariate analysis of overall and disease-specific survival for patients with OPSCC patients treated with resection

\begin{tabular}{|c|c|c|c|c|}
\hline \multirow[b]{2}{*}{ Parameter } & \multicolumn{2}{|c|}{ 5-year overall survival } & \multicolumn{2}{|c|}{ 5-year disease-specific survival } \\
\hline & $\mathrm{HR}(95 \% \mathrm{Cl})$ & $p$ value & $\mathrm{HR}(95 \% \mathrm{Cl})$ & $p$ value \\
\hline HR-HPV DNA (Positive vs. negative) & $0.46(0.26-0.81)$ & 0.007 & $0.41(0.18-0.90)$ & 0.027 \\
\hline p16 INK4a (High vs. low) & $0.23(0.16-0.57)$ & $<0.001$ & $0.22(0.09-0.52)$ & 0.001 \\
\hline pRB (High vs. low) & $2.54(1.46-4.41)$ & 0.001 & $3.20(1.46-6.99)$ & 0.004 \\
\hline Cyclin D1 (High vs. low) & $1.59(0-2.55)$ & 0.053 & $1.55(0.82-2.94)$ & 0.18 \\
\hline p53 (High vs. low) & $1.79(1.12-2.86)$ & 0.015 & $1.52(0.80-2.87)$ & 0.20 \\
\hline High p16 $6^{\text {INK4a }} / H R$-HPV DNA positive vs. others & $0.30(0.16-0.57)$ & $<0.001$ & $0.26(0.10-0.64)$ & 0.004 \\
\hline High p16 $6^{\text {INK4a }} /$ low pRB vs. Others & $0.32(0.18-0.45)$ & $<0.001$ & $0.25(0.11-0.60)$ & 0.002 \\
\hline High p16 $6^{\text {INK4a } / l o w ~ p R B / l o w ~ c y c l i n ~ D 1 / l o w ~ p 53 ~ v s . ~ o t h e r s ~}$ & $0.36(0.19-0.38)$ & 0.001 & $0.25(0.09-0.65)$ & 0.005 \\
\hline
\end{tabular}

Abbreviations: $H R$ hazard ratio for death, $\mathrm{Cl}$ confidence interval; $P<0.05$ was considered statistically significant 


\section{Abbreviations}

DSS: Disease-specific survival; HPV: Human papillomavirus; HR: Hazard ratio; NPV: Negative predictive value; OPSCC: Oropharyngeal squamous cells carcinoma; OS: Overall survival; PCR: Polymerase chain reaction; PPV: Positive predictive value; TMA: Tissue microarray

\section{Acknowledgments}

The authors thank Jasmin Germann, Doris Kradolfer and Claudia Zimmermann for excellent technical assistance. The authors thank the contributors to the Swiss Cohort of Oropharyngeal Cancer Patients (SCOC) for providing clinical data and tumor tissue samples.

\section{Funding}

The Swiss Cancer League, Berne, Switzerland (KLS-3153-02-2013), and the CTU Kommission, Kantonsspital St. Gallen, St. Gallen, Switzerland (CTU 13/26) supported the study.

\section{Availability of data and materials}

All data generated or analysed during this study are included in the published article and its supplementary information files.

\section{Authors' contributions}

MP: Histological analysis, and drafting of the manuscript. MB: Study design, analysis of clinical features, and drafting of the manuscript. DF: Molecular analysis, and drafting of the manuscript. SS: Drafting of the manuscript, and study supervision. WJ: Study design, histological analysis, interpretation of data, and drafting of the manuscript. All authors approved the final manuscript as submitted.

\section{Ethics approval and consent to participate}

The Ethics Committee Ostschweiz (EKOS), St. Gallen, Switzerland approved the study (EKSG 12/106/L/1B).

\section{Consent for publication}

Not applicable.

\section{Competing interests}

The authors declare that they have no completing interests.

\section{Publisher's Note}

Springer Nature remains neutral with regard to jurisdictional claims in published maps and institutional affiliations.

\section{Author details}

${ }^{1}$ Department of Otorhinolaryngology, Head and Neck Surgery, Kantonsspital St.Gallen, St. Gallen, Switzerland. ²Department of Otorhinolaryngology, University Hospital Heidelberg, Heidelberg, Germany. ${ }^{3}$ Institute of Pathology, Kantonsspital St. Gallen, Rorschacher Strasse 95, 9007 St. Gallen, Switzerland. ${ }^{4}$ Department of Otorhinolaryngology, Head and Neck Surgery,

UniversitätsSpital Zürich, Zurich, Switzerland.

Received: 15 April 2018 Accepted: 26 August 2018

Published online: 06 September 2018

\section{References}

1. Taberna M, et al. Human papillomavirus-related oropharyngeal cancer. Ann Oncol. 2017;28(10):2386-98.

2. Huang $\mathrm{SH}$, et al. Refining American joint committee on Cancer/Union for International Cancer Control TNM stage and prognostic groups for human papillomavirus-related oropharyngeal carcinomas. J Clin Oncol. 2015;33(8):836-45.

3. Horne ZD, et al. Confirmation of proposed human papillomavirus riskadapted staging according to AJCC/UICC TNM criteria for positive oropharyngeal carcinomas. Cancer. 2016;122(13):2021-30.

4. O'Sullivan B, et al. Development and validation of a staging system for HPVrelated oropharyngeal cancer by the international collaboration on oropharyngeal cancer network for staging (ICON-S): a multicentre cohort study. Lancet Oncol. 2016;17(4):440-51.

5. Husain ZA, et al. A comparison of prognostic ability of staging systems for human papillomavirus-related oropharyngeal squamous cell carcinoma. JAMA Oncol. 2017;3(3):358-65.
6. Groves IJ, Coleman N. Pathogenesis of human papillomavirus-associated mucosal disease. J Pathol. 2015;235(4):527-38.

7. Castellsague $X$, et al. HPV involvement in head and neck cancers: comprehensive assessment of biomarkers in 3680 patients. J Natl Cancer Inst. 2016;108(6):djv403.

8. $\mathrm{Yu} Z$, et al. Cyclin d1 is a valuable prognostic marker in oropharyngeal squamous cell carcinoma. Clin Cancer Res. 2005;11(3):1160-6.

9. Weinberger PM, et al. Molecular classification identifies a subset of human papillomavirus--associated oropharyngeal cancers with favorable prognosis. J Clin Oncol. 2006;24(5):736-47.

10. Ang KK, et al. Human papillomavirus and survival of patients with oropharyngeal cancer. N Engl J Med. 2010;363(1):24-35.

11. Jung $A C$, et al. Biological and clinical relevance of transcriptionally active human papillomavirus (HPV) infection in oropharynx squamous cell carcinoma. Int J Cancer. 2010;126(8):1882-94.

12. Lewis JS Jr, et al. p16 positive oropharyngeal squamous cell carcinoma:an entity with a favorable prognosis regardless of tumor HPV status. Am J Surg Pathol. 2010;34(8):1088-96.

13. Hong AM, et al. Use of cyclin D1 in conjunction with human papillomavirus status to predict outcome in oropharyngeal cancer. Int J Cancer. 2011;128(7):1532-45.

14. Schache $A G$, et al. Evaluation of human papilloma virus diagnostic testing in oropharyngeal squamous cell carcinoma: sensitivity, specificity, and prognostic discrimination. Clin Cancer Res. 2011;17(19):6262-71.

15. Ukpo OC, et al. High-risk human papillomavirus E6/E7 mRNA detection by a novel in situ hybridization assay strongly correlates with p16 expression and patient outcomes in oropharyngeal squamous cell carcinoma. Am J Surg Pathol. 2011;35(9):1343-50.

16. Lin RJ, et al. Cyclin D1 overexpression is associated with poor prognosis in oropharyngeal cancer. J Otolaryngol Head Neck Surg. 2013:42:23.

17. Scantlebury JB, et al. Cyclin D1-a prognostic marker in oropharyngeal squamous cell carcinoma that is tightly associated with high-risk human papillomavirus status. Hum Pathol. 2013:44(8):1672-80.

18. Ryu $\mathrm{CH}$, et al. Human papillomavirus-related cell cycle markers can predict survival outcomes following a transoral lateral oropharyngectomy for tonsillar squamous cell carcinoma. J Surg Oncol. 2014;110(4):393-9.

19. Holzinger $D$, et al. Identification of oropharyngeal squamous cell carcinomas with active HPV16 involvement by immunohistochemical analysis of the retinoblastoma protein pathway. Int J Cancer. 2013;133(6):1389-99.

20. Broglie MA, et al. Impact of human papillomavirus on outcome in patients with oropharyngeal cancer treated with primary surgery. Head Neck. 2017:39(10):2004-15.

21. Gronhoj Larsen C, et al. Correlation between human papillomavirus and p16 overexpression in oropharyngeal tumours: a systematic review. $\mathrm{Br} J$ Cancer. 2014:110(6):1587-94

22. Yoshikawa $\mathrm{H}$, et al. Detection and typing of multiple genital human papillomaviruses by DNA amplification with consensus primers. Jpn J Cancer Res. 1991;82(5):524-31.

23. Smeets SJ, et al. A novel algorithm for reliable detection of human papillomavirus in paraffin embedded head and neck cancer specimen. Int J Cancer. 2007;121(11):2465-72.

24. Snow AN, Laudadio J. Human papillomavirus detection in head and neck squamous cell carcinomas. Adv Anat Pathol. 2010;17(6):394-403.

25. Jordan RC, et al. Validation of methods for oropharyngeal cancer HPV status determination in US cooperative group trials. Am J Surg Pathol. 2012;36(7):945-54

26. Ndiaye $C$, et al. HPV DNA, E6/E7 mRNA, and p16INK4a detection in head and neck cancers: a systematic review and meta-analysis. Lancet Oncol. 2014:15(12):1319-31.

27. Boyer SN, Wazer DE, Band V. E7 protein of human papilloma virus-16 induces degradation of retinoblastoma protein through the ubiquitinproteasome pathway. Cancer Res. 1996;56(20):4620-4.

28. Fakhry $\mathrm{C}$, et al. Improved survival of patients with human papillomaviruspositive head and neck squamous cell carcinoma in a prospective clinical trial. J Natl Cancer Inst. 2008;100(4):261-9.

29. Fischer $C A$, et al. Is the improved prognosis of p16 positive oropharyngeal squamous cell carcinoma dependent of the treatment modality? Int J Cancer. 2010:126(5):1256-62.

30. Haughey BH, Sinha P. Prognostic factors and survival unique to surgically treated p16+ oropharyngeal cancer. Laryngoscope. 2012;122(Suppl 2):S13-33.

31. Dale OT, et al. Long-term survival outcomes in patients with surgically treated oropharyngeal cancer and defined human papilloma virus status. Laryngol Otol. 2016;130(11):1048-53. 